\title{
PERBANYAKAN INOKULUM FUNGI MIKORIZA GLOMUS DAN GIGASPORA DENGAN BERBAGAI FORMULA PEMBAWA PADA INANG JAGUNG
}

\author{
Faisal Al Asad ${ }^{1 *}$, Eny Rokhminarsi ${ }^{2}$ \\ ${ }^{1}$ Program Studi Agroteknologi, Universitas Wiralodra, Indramayu \\ ${ }^{2}$ Program Studi Agroteknologi, Universitas Jenderal Soedirman, Purwokerto \\ faisalalasad@unwir.ac.id
}

\begin{abstract}
Mycorrhizal are fungi that live around plant roots and play a role in helping the absorption of nutrients, especially elements of $\mathrm{P}$, water and can protect plant roots from soil pathogens. Therefore, this fungus can be used as biological fertilizer. Efforts to reproduce these fungi generally use zeolite as carrier media. The use of zeolite as a mycorrhizal carrier media is considered not economical enough, so it is necessary to find an alternative carrier that is more economical and easy to obtain, such as wood charcoal, natural phosphate rock (BFA), and Ultisol ground flour. This research was carried at the greenhouse of Departement of Agriculture Jenderal Soedirman University Purwokerto on Mei up to September 2014 used a Randomized Block Design (RBD) pot of experiment that three replicates. The first factor to be tested was the mycorrhizal genus, i.e: Glomus, Gigaspora, a mixture of the mycorrhizal genus Glomus and Gigaspora. The second factor to be tested was the carrier, i.e: soil ultisol flour sieves 121 mesh, soil ultisol flour sieves 121 mesh + BFA (1:1), soil ultisol flour sieves 121 mesh + BFA (1:1) + charcoal, and soil ultisol flour sieves 121 mesh + charcoal. The result of the research showed that glomus and gigaspora combined produced spores most a lot on the vegetative phase of the corn plant. The growth of a host plant is not influenced by the genus but influenced by the carrier and the carrier used for best is flour land ultisol + BFA + charcoal (1: 1: 1). The corn plant growth and development of mycorrhizal were not affected by the interaction of genus mycorrhizal and formula carrier.
\end{abstract}

Kaywords: carrier, glomus. gigaspore. Corn mycorrhizal.

\begin{abstract}
Abstrak
Mikoriza merupakan fungi yang hidup disekitar perakaran tanaman dan berperan dalam membantu penyerapan unsur hara khususnya unsur $\mathrm{P}$, air dan dapat melindungi akar tanaman dari patogen tanah. Oleh karena itu, cendawan ini dapat digunakan sebagai pupuk hayati. Upaya untuk memperbanyak fungi ini umumnya menggunakan media pembawa zeolit. Penggunaan zeolit sebagai media pembawa mikoriza dinilai belum cukup ekonomis, sehingga perlu dicari alternatif media pembawa yang lebih ekonomis dan mudah didapat seperti arang kayu, batuan fosfat alam (BFA), dan tepung tanah Ultisol. Penelitian ini dilakukan di screen house Fakultas Pertanian Universitas Jenderal Soedirman Purwokerto pada bulan Mei September 2014 menggunakan Rancangan Acak Kelompok (RAK) dua faktor berupa percobaan pot yang diulang tiga kali. Faktor pertama yang dicoba adalah genus mikoriza, yang terdiri dari : Glomus, Gigaspora, campuran genus mikoriza Glomus dan Gigaspora. Faktor kedua yang dicoba adalah formula pembawa, yaitu : tepung tanah Ultisol lolos saring 121 mesh, tepung tanah Ultisol lolos saringan 121 mesh + BFA (1:1), tepung tanah Ultisol lolos saringan 121 mesh + BFA + arang (1:1:1), dan tepung tanah Ultisol saringan 121 mesh + arang (1:1). Hasil penelitian menunjukkan campuran Glomus dan Gigaspora menghasilkan spora paling banyak pada fase vegetatif tanaman jagung, pertumbuhan tanaman jagung tidak
\end{abstract}


dipengaruhi genus mikoriza tetapi dipengaruhi oleh formula pembawa, formula pembawa terbaik berupa tepung tanah Ultisol + BFA + arang (1:1:1). Pertumbuhan tanaman jagung dan perkembangan

\section{Pendahuluan}

Pertambahan penduduk di Indonesia dari tahun ke tahun semakin meningkat. Tercatat pada tahun 2000, 2010, dan 2020 penduduk Indonesia sebesar 206,3 juta, 237,6 juta, dan 270,2 juta (BPS, 2010; BPS, 2021). Oleh karena itu, perlu upaya untuk meningkatkan produksi pangan yang berkelanjutan. Peningkatan produksi pangan dapat dilakukan dengan cara intensifikasi dan ekstensifikasi. Cara yang umum dilakukan untuk meningkatkan produksi pangan adalah intensifikasi, yaitu penggunaan pupuk anorganik.

Penggunaan pupuk anorganik secara berlebihan menyebabkan kerusakan fisik, kimiawi, dan biologis tanah serta menurunkan kesuburan tanah (Sofyan et al., 2019). Penggunaan pupuk anorganik secara terus menerus menimbulkan efek negatif terhadap tanah seperti turunnya kandungan bahan organik dan aktivitas mikroorganisme tanah, tanah menjadi padat dan terjadi polusi lingkungan (Sharma dan Mitra, 1991) sehingga mempengaruhi produksi tanaman yang diusahakan. Oleh karena itu, perlu dicari alternatif teknologi yang dapat mengurangi penggunaan pupuk anorganik tersebut. Salah satu cara untuk menggantikan sebagaian atau seluruh fungsi pupuk anorganik adalah dengan menggunakan pupuk hayati yang mengandung Fungi Mikoriza Arbuskula.

Fungi Mikoriza Arbuskula (FMA) merupakan jenis fungi yang bersifat obligat parasit, sehingga tidak dapat diinokulasi dengan teknik mikrobiologi, artinya hanya dapat tumbuh pada akar tumbuhan hidup. Hubungan tumbuhan dan FMA bermanfaat meningkatkan kemampuan tanaman dalam menyerap air dan unsur hara (Goltapeh et al., 2008) dan berperan dalam pengendalian penyakit tanaman (Talanca, 2005). Genus FMA yang sering dijumpai di lapangan diantaranya adalah Glomus dan Gigaspora. mikoriza tidak terpengaruh oleh interaksi antara genus mikoriza dan formula pembawa.

Kata kunci: formula pembawa. glomus. gigaspora. jagung. mikoriza.

Genus-genus mikoriza ini mempunyai fungsi meningkatkan serapan hara sehingga dapat meminimalkan penggunaan pupuk kimia dan tahan terhadap kekeringan. Banyak sekali manfaat yang didapat dengan keberadaan FMA ini. Oleh karena itu, perlu suatu upaya untuk mengembangkan fungi ini. Salah satu cara untuk mengembangkan cendawan ini adalah dengan cara memperbanyak jumlah sporanya melalui berbagai media atau formula pembawanya.

Penelitian ini bertujuan untuk memperoleh genus mikoriza yang cocok untuk pertumbuhan vegetatif tanaman inang jagung dengan jumlah spora paling banyak, mendapatkan formula pembawa yang tepat untuk perkembangan mikoriza dan pertumbuhan vegetatif tanaman inang jagung, mengetahui interaksi genus mikoriza dan formula pembawa yang memberikan pertumbuhan vegetatif tanaman inang jagung paling baik dan jumlah spora terbanyak.

\section{Bahan dan Metode}

Penelitian dilakukan pada bulan Mei September 2014 di screen house Fakultas Pertanian Universitas Jenderal Soedirman Purwokerto. Bahan yang digunakan dalam penelitian ini adalah mikoriza genus Glomus dan Gigaspora, BFA, arang kayu, benih jagung manis, kompos, formalin, tanah Ultisol, $\mathrm{HCl} 2 \%, \mathrm{KOH} 10 \%$, label, polibag, pupuk Urea, SP-36, KCl. Alat yang digunakan dalam penelitian ini meliputi: mikroskop, pengaduk kaca, gelas obyek, tabung gelas, cawan petri, erlenmeyer, gelas beker, gelas ukur, timbangan, ayakan, handsprayer, ember, gembor, timbangan, cutter, termohigrometer, ember, pinset, rumah plastik, alat tulis, kamera, saringan (siever).

Penelitian berupa percobaan pot disusun dalam Rancangan Acak Kelompok (RAK) dengan dua faktor, yaitu genus 
mikoriza (G) dan formula pembawa (F). Genus mikoriza terdiri atas : Glomus (G1), Gigaspora (G2), campuran Glomus dan Gigaspora (G3). Formula pembawa yang dicoba terdiri atas empat macam, yaitu : tepung tanah Ultisol lolos saringan 121 mesh (F1), tepung tanah Ultisol lolos saringan 121 mesh + BFA (1:1) (F2), tepung tanah Ultisol lolos saringan 121 mesh + BFA + arang (1:1:1) (F3), tepung tanah Ultisol saringan 121 mesh + arang (1:1) (F4). Terdapat 12 kombinasi perlakuan dan diulang tiga kali sehingga terdapat 36 unit percobaan.

Variabel yang diamati terdiri atas jumlah spora mikoriza, kolonisasi, tinggi tanaman, bobot akar segar, bobot akar kering, bobot tanaman segar, jumlah daun. Data pengamatan dianalisis menggunakan uji $\mathrm{F}$ untuk mengetahui tingkat signifikasi masingmasing perlakuan dan jika berbeda nyata dilanjutkan dengan uji Duncan Multiple Range Test (DMRT) pada taraf kesalahan 5\%.

\section{Hasil dan Pembahasan}

\section{Pengaruh genus mikoriza dan formula pembawa terhadap perkembangan mikoriza}

Hasil uji F (Tabel 1) menunjukkan bahwa genus mikoriza berpengaruh nyata terhadap jumlah spora, tetapi tidak berpengaruh nyata terhadap kolonisasi. Namun demikian, nilai kolonisasii menunjukkan nilai yang sangat tinggi. O'Connor et al. (2001) menyebutkan nilai kolonisasi mikoriza digolongkan menjadi empat yaitu : tidak terkoloni (nilai kolonisasi 0\%), rendah (nilai kolonisasi<10\%), sedang (nilai kolonisasi 10$30 \%$ ), dan tinggi (nilai kolonisasi $>30 \%$ ).

Campuran Glomus dan Gigaspora menghasilkan jumlah spora paling banyak dibandingkan perlakuan mandiri G1 atau G2 (Tabel 2). Penggunaan tanah Ultisol pada semua unit percobaan membuat genus mikoriza ini berkembang baik. Tanah Ultisol mempunyai karakteristik masam, bahan organik rendah, nutrisi makro yang rendah, dan memiliki ketersediaan $P$ yang sangat rendah (Fitriatin et al., 2014). Mikoriza akan berkembang baik yang ditandai dengan kolonisasi yang optimal apabila $\mathrm{pH}$ media tanam masam dan pada $\mathrm{pH} 4,7 ; 5,6$; dan 6,4 kolonisasi mikoriza akan meningkat (Nurlaeny et al., 1996; Singh, 2004).

Campuran genus mikoriza Glomus dan Gigaspora menyebabkan aktivitas di sekitar perakaran meningkat. Kondisi 18ancer diduga sebagai penyebab jumlah koloni di sekitar perakaran meningkat, sehingga kolonisasi FMA di sekitar perakaran sangat tinggi. Perlakuan G1 dan G2 kurang menghasilkan kolonisasi yang tinggi karena pada G1 dan G2 tidak ada persaingan dalam kolonisasi, sehingga kolonisasi mikoriza lebih sedikit dibandingkan G3. Infeksi mikoriza pada akar salah satunya ditandai dengan adanya arbuskula, hifa, dan vesikula pada jaringan akar tanaman (Gambar 1).

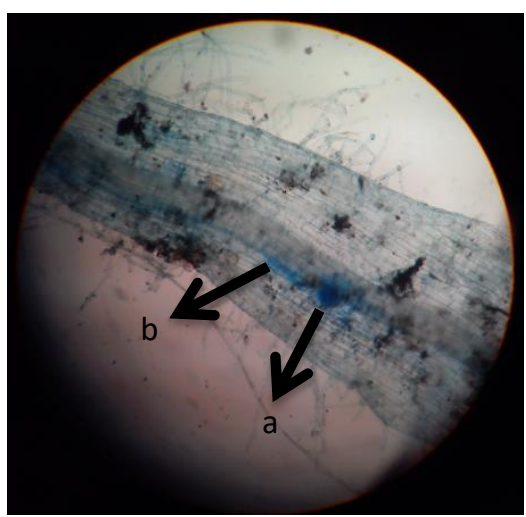

Keterangan $: a=$ vesikula dan $b=$ hifa

Gambar 1. Infeksi mikoriza pada akar tanaman jagung

Tabel 1 menunjukkan tidak ada pengararuh yang nyata terhadap kolonisasi mikoriza dari perlakuan genus mikoriza, formula pembawa, dan interaksi genus mikoriza dengan formula pembawa pada tanaman jagung. Kondisi stress diduga menjadi penyebab 18ancer18e kolonisasi yang tidak nyata terhadap semua perlakuan. Menurut Asad (2018), meskipun persentase infeksi mikoriza pada akar dan pembentukan spora punya hubungan erat, namun tidak dapat dikatakan selalu mempunyai hubungan positif. 
Hal ini diduga karena suhu di tempat penelitian yang sangat fluktuatif atau berubahubah sangat cepat. Suhu 19 anc mencapai $25^{\circ} \mathrm{C}$ sampai $38^{\circ} \mathrm{C}$. Menurut Elfiati et al., (2007) suhu optimum bagi kolonisasi adalah $28^{0} \mathrm{C}$ sampai $35^{\circ} \mathrm{C}$.

Tabel. 1. Analisis ragam perbanyakan cendawan mikoriza Glomus dan Gigaspora pada tanaman jagung dengan beberapa formula pembawa.

\begin{tabular}{|c|c|c|c|c|}
\hline No & Variabel & Genus Mikoriza & $\begin{array}{c}\text { Formula } \\
\text { Pembawa }\end{array}$ & $\begin{array}{l}\text { Genus Mikoriza x } \\
\text { Formula Pembawa }\end{array}$ \\
\hline 1 & Tinggi tanaman $(\mathrm{cm})$ & $0,25^{\mathrm{tn}}$ & $3,84^{\mathrm{n}}$ & $0,16^{\mathrm{tn}}$ \\
\hline 2 & Jumlah daun & $1,99^{\mathrm{tn}}$ & $31,30^{\mathrm{sn}}$ & $1,14^{\mathrm{tn}}$ \\
\hline 3 & Bobot tajuk segar (g) & $0,21^{\mathrm{tn}}$ & $8,18^{\mathrm{sn}}$ & $0,62^{\mathrm{tn}}$ \\
\hline 4 & Bobot tajuk kering $(\mathrm{g})$ & $3,19^{\operatorname{tn}}$ & $4,35^{\mathrm{n}}$ & $0,51^{\mathrm{tn}}$ \\
\hline 5 & Bobot akar segar (g) & $0,13^{\text {tn }}$ & $10,77^{\mathrm{sn}}$ & $1,49^{\mathrm{tn}}$ \\
\hline 6 & Kolonisasi & $1,22^{\mathrm{tn}}$ & $1,09^{\mathrm{tn}}$ & $0,73^{\text {tn }}$ \\
\hline 7 & Jumlah spora & $5,46^{\mathrm{n}}$ & $0,47^{\mathrm{tn}}$ & $2,24^{\mathrm{tn}}$ \\
\hline
\end{tabular}

Keterangan: $\mathrm{sn}=$ sangat nyata, $\mathrm{n}=$ nyata, $\mathrm{tn}=$ tidak nyata, tingkat kesalahan $5 \%$

Pengaruh genus dan formula terhadap perkembangan tanaman jagung

Tabel 2 menunjukkan tanaman paling tinggi ditunjukan oleh formula pembawa berupa campuran tepung tanah Ultisol lolos saringan 121 mesh + BFA + arang (1:1:1) dibandingkan formula pembawa berupa tepung tanah Ultisol lolos saring 121 mesh + arang (1:1), namun perlakuan formula pembawa berupa campuran tepung tanah Ultisol lolos saringan 121 mesh + BFA + arang tidak berbeda nyata dengan formula pembawa berupa tepung tanah Ultisol lolos saringan 121 mesh dan formula pembawa berupa tepung tanah Ultisol lolos saringan 121 mesh + BFA (1:1). Formula pembawa berupa campuran tepung tanah Ultisol lolos saringan 121 mesh + BFA + arang (1:1:1) merupakan perlakuan terbaik untuk meningkatkan tinggi tanaman jagung.

Formula pembawa arang kayu, BFA, dan tepung tanah Ultisol mampu menjadikan lahan yang kurang subur menjadi lahan yang lebih produktif. Kandungan fosfor (P) pada BFA yang diserap tanaman sangat membantu dalam proses fotosintesis, respirasi, transfer. Penyimpanan 19ancer, memindahkan 19ancer seperti ATP dan ADP, pembelahan, dan perbesaran sel (Winarso, 2005). Fungsi pembelahan dan perbesaran sel ini erat kaitannya dengan tinggi tanaman. Tanaman akan semakin tinggi apabila fosfor yang dibutuhkan tanaman tercukupi. Penggunaan kayu sebagai bahan pembenah tanah membuat air dan hara dalam tanah tidak hilang akibat aliran permukaan (run off) dan pencucian (leaching), sehingga memungkinkan penghematan pupuk dan mengurangi polusi pada lingkungan sekitar (Ferizal dan Basri, 2011).

Formula Pembawa berupa campuran tepung tanah Ultisol lolos saring 121 mesh + BFA + arang (1:1:1) memberikan pengaruh yg baik pada jumlah daun, bobot tajuk segar, bobot tajuk kering, bobot akar segar. Formula F3 dan F2 (Tabel. 2) menghasilkan jumlah daun paling banyak. Hal ini karena keberadaan BFA yang mengandung fosfat yang diserap tanaman akan membantu proses pembelahan sel, sehingga dapat meningkatkan pertumbuhan tanaman. Pengaruh arang dalam mengatur aerasi, sirkulasi dalam media tanam menyebabkan perakaran tumbuh dengan baik (Komarayati et al., 2004) sehingga penyerapan unsur hara berjalan lancar. Jumlah daun yg banyak, tanaman yang tinggi menghasilkan penambahan bobot tajuk segar, bobot tajuk kering, dan bobot akar segar.

Variabel bobot tajuk segar pada perlakuan genus mikoriza dan interaksi genus mikoriza dengan formula pembawa menunjukkan tidak berpengaruh nyata, tetapi ada pengaruh pada perlakuan formula 
pembawa. Formula pembawa berupa campuran tepung tanah Ultisol lolos saringan 121 mesh + BFA + arang (1:1:1) memberikan bobot tajuk segar yang lebih tinggi, yaitu sebesar $40 \%$ dibandingkan formula pembawa berupa tepung tanah Ultisol lolos saringan 121 mesh dari perlakuan F1. Hal ini karena formula F3 yang terdiri dari tanah Ultisol, BFA, arang menghasilkan lingkungan yang dikehendaki tanaman, sehingga penyerapan air dan unsur hara berjalan optimal. 
Tabel. 2. Angka rata-rata perkembangan mikoriza dan tanggap tanaman jagung terhadap genus mikoriza dan formula pembawa pada perbanyakan inokulum FMA

\begin{tabular}{|c|c|c|c|c|c|c|c|}
\hline \multirow{2}{*}{ Perlakuan } & \multicolumn{7}{|c|}{ Varibel yang diamati } \\
\hline & TT & $\mathrm{JD}$ & BTS & BTK & BAS & Kolonisasi (\%) & $\mathrm{JS}$ \\
\hline \multicolumn{8}{|c|}{ Genus Mikoriza } \\
\hline Glomus & 67.99 & 6.58 & 30.67 & 3.55 & 7.34 & 60.00 & $17.92 \mathrm{~b}$ \\
\hline Gigaspora & 68.58 & 6.08 & 32.00 & 4.23 & 7.30 & 66.67 & $17.75 \mathrm{~b}$ \\
\hline Campuran Glomus dan Gigaspora & 70.19 & 6.42 & 33.00 & 4.49 & 7.84 & 69.17 & $25.17 \mathrm{a}$ \\
\hline F hit $\mathrm{G}$ & 0.25 & 1.99 & 0.21 & 3.19 & 0.13 & 1.22 & $5.46^{*}$ \\
\hline $\mathrm{F}$ tab $5 \%$ & 3.44 & 3.44 & 3.44 & 3.44 & 3.44 & 3.44 & 3.44 \\
\hline \multicolumn{8}{|c|}{ Formula Pembawa } \\
\hline $\begin{array}{l}\text { Tepung tanah Ultisol lolos saringan } \\
121 \text { mesh }\end{array}$ & $70.69 \mathrm{a}$ & $5.78 \mathrm{~b}$ & $29.33 \mathrm{bc}$ & $4.02 \mathrm{~b}$ & $5.46 \mathrm{c}$ & 68.89 & 20.67 \\
\hline $\begin{array}{l}\text { Tepung tanah Ultisol lolos saringan } 121 \\
\text { mesh + BFA (1:1) }\end{array}$ & $69.53 \mathrm{a}$ & $7.33 \mathrm{a}$ & $35.56 \mathrm{ab}$ & $4.23 \mathrm{~b}$ & $8.41 \mathrm{~b}$ & 70.00 & 18.89 \\
\hline $\begin{array}{l}\text { Tepung tanah Ultisol lolos saringan } 121 \\
\text { mesh + BFA + arang }(1: 1: 1)\end{array}$ & $73.78 \mathrm{a}$ & $7.33 \mathrm{a}$ & $41.11 \mathrm{a}$ & $4.85 \mathrm{a}$ & $11.50 \mathrm{a}$ & 58.89 & 19.44 \\
\hline $\begin{array}{l}\text { Tepung tanah Ultisol lolos saringan } 121 \\
\text { mesh }+ \text { arang }(1: 1)\end{array}$ & $61.68 \mathrm{~b}$ & $5.00 \mathrm{~b}$ & $21.56 \mathrm{c}$ & $3.26 \mathrm{c}$ & $4.62 \mathrm{c}$ & 63.33 & 22.11 \\
\hline F hit F & $3.84 *$ & $31.30 * *$ & $8.18 * *$ & $4.35 *$ & $10.77 * *$ & 1.09 & 0.47 \\
\hline $\mathrm{F}$ tab $5 \%$ & 3.05 & 3.05 & 3.05 & 3.05 & 3.05 & 3.05 & 3.05 \\
\hline \multicolumn{8}{|c|}{ Kombinasi genus mikoriza dengan formula pembawa } \\
\hline $\begin{array}{l}\text { Kombinasi Glomus dan Tepung tanah } \\
\text { Ultisol lolos saringan } 121 \text { mesh }\end{array}$ & 72.17 & 6.00 & 26.67 & 3.50 & 4.39 & 66.67 & 16.33 \\
\hline $\begin{array}{l}\text { Kombinasi Glomus dan tepung tanah } \\
\text { Ultisol lolos saringan } 121 \text { mesh + BFA } \\
(1: 1)\end{array}$ & 66.58 & 7.67 & 36.67 & 3.45 & 8.18 & 56.67 & 20.00 \\
\hline $\begin{array}{l}\text { Kombinasi Glomus dan tepung tanah } \\
\text { Ultisol lolos saringan } 121 \text { mesh + BFA } \\
+ \text { arang }(1: 1: 1)\end{array}$ & 72.33 & 8.00 & 42.00 & 4.74 & 13.47 & 53.33 & 15.67 \\
\hline $\begin{array}{l}\text { Kombinasi Glomus dan tepung tanah } \\
\text { Ultisol lolos saringan } 121 \text { mesh }+ \\
\text { arang }(1: 1)\end{array}$ & 60.87 & 4.67 & 17.33 & 2.49 & 3.33 & 63.33 & 19.67 \\
\hline $\begin{array}{l}\text { Kombinasi Gigaspora dan Tepung } \\
\text { tanah Ultisol lolos saringan } 121 \text { mesh }\end{array}$ & 70.42 & 5.67 & 30.00 & 4.24 & 6.68 & 73.33 & 17.00 \\
\hline Kombinasi Gigaspora dan Tepung & 70.08 & 7.00 & 30.00 & 4.44 & 5.95 & 70.00 & 11.00 \\
\hline
\end{tabular}


tanah Ultisol lolos saringan 121 mesh + BFA $(1: 1)$

Kombinasi Gigaspora dan tepung tanah Ultisol lolos saringan 121 mesh + BFA + arang (1:1:1)

Kombinasi Gigaspora dan Tepung

tanah Ultisol lolos saringan 121 mesh +

Kombinasi campuran Glomus dan

Gigaspora dengan tepung tanah Ultisol

Kombinasi campuran Glomus dan

Gigaspora dengan tepung tanah Ultisol

Kombinasi campuran Glomus da

Gigaspora dengan tepung tanah Ultisol lolos saringan 121 mesh + BFA + arang

(1:1:1)

Kombinasi campuran Glomus dan

Gigaspora dengan tepung tanah Ultisol 
Formula pembawa berupa campuran tepung tanah Ultisol lolos saringan 121 mesh + BFA + arang (1:1:1) juga menunjukkan bobot tajuk kering paling tinggi dibandingkan formula lainnya. Besarnya nilai bobot tajuk kering mencerminkan banyaknya unsur hara yang dapat diserap dan digunakan untuk metabolisme dalam tubuh tanaman (Irianto, 2009).

Bobot akar segar dipengaruhi oleh perlakuan formula pembawa secara nyata, sedangkan perlakuan genus mikoriza dan interaksi genus mikoriza dengan formula tidak memberikan pengaruh nyata. Bobot akar segar tertinggi dicapai oleh formula pembawa berupa campuran tepung tanah Ultisol lolos saringan 121 mesh + BFA + arang (1:1:1) yaitu sebesar $11.5 \mathrm{~g}$ dan bobot akar segar terendah pada formula pembawa berupa tepung tanah Ultisol lolos saringan 121 mesh + arang (1:1) yakni sebesar $4.62 \mathrm{~g}$, yaitu dengan peningkatan sebesar $149 \%$ dibandingkan formula pembawa berupa campuran tepung tanah Ultisol lolos saringan 121 mesh + BFA + arang (1:1:1). Peran BFA dalam perkembangan sel, mempercepat pertumbuhan tanaman dan peran arang dalam memperbaiki kondisi tanah serta meningkatkan produksi tanaman khususnya pada tanah-tanah yang kurang subur menyebabkan kondisi yang menguntungkan bagi tanaman, sehingga pertumbuhan tanaman menjadi maksimal.

\section{Kesimpulan}

1. Campuran Glomus dan Gigaspora menghasilkan spora paling banyak pada fase vegetatif tanaman jagung.

2. Pertumbuhan tanaman jagung tidak dipengaruhi genus mikoriza tetapi dipengaruhi oleh formula pembawa, dan formula pembawa terbaik berupa tepung tanah Ultisol + BFA + arang $(1: 1: 1)$.

3. Pertumbuhan tanaman jagung dan perkembangan mikoriza tidak dipengaruh oleh interaksi antara genus mikoriza dan formula pembawa.

\section{Ucapan Terimakasih}

Terimakasih kepada Ir. Eny Rokhminarsi, M.P. yang telah mendanai penelitian ini. Terimakasih juga saya ucapkan kepada Tim Mikoriza 2014 dan semua pihak yang telah terlibat dalam penelitian ini.

\section{Daftar Pustaka}

Asad, F. A. 2018. Kajian Pemanfaatan FMA dan Pengurangan Pupuk N, P untuk Meningkatkan Pertumbuhan, Produksi, dan Kadar Metabolit Jintan Hitam (Nigella sativa L.). IPB University, Bogor
Badan Pusat Statistik. (2010). Tiap 10 Tahun, Sensus Penduduk Mencatat Peningkatan Jumlah Penduduk Indonesia. Badan Pusat Statistik. Jakarta

(2021). Hasil Sensus Penduduk 2020. Badan Pusat Statistik. Jakarta

Elfiati, D. dan Delvian. (2007). Keanekaragaman Cendawan Mikoriza Arbuskula (CMA) Berdasarkan Ketinggian Tempat. Jurnal Ilmu-Ilmu Pertanian Indonesia. 3: 372-378

Ferizal, M dan Basri. (2011). Arang Hayati (BIOCHAR) sebagai Bahan Pembenah Tanah. Nangroe Aceh Darussalam : Balai Pengkajian Teknologi Pertanian, Badan Litbang Pertanian.

Fitriatin, B.N., Yuniarti, A., Turmuktini, T., dan Ruswandi, F.K. (2014). The Effect of Phosphate Solubilizing Microbe Producing Growth Regulators on Soil Phosphate, Growth and Yield of Maize and Fertilizer Efficiency on Ultisol. Eurasian Journal of Soil Science 3:101107

Goltapeh, E. M., Danesh, Y.R., Prasad, R., dan Varma, A. 2008. Mycorrhizal Fungi: What We Know and What Should We Know?. In Varma A (Eds). 2008. Mycorrhiza. 3rd ed.Springer, Berlin Heidelberg.

Irianto, R.S.B. (2009). Pengaruh Inokulasi Fungi Mikoriza Arbuskular terhadap Pertumbuhan Bibit Jarak Pagar di Persemaian. Jurnal Penelitian Hutan dan Konservasi Alam. 6: 195-201

Komarayati, S., Setiawan, D., Mahpudin. (2004). Beberapa Sifat dan Pemanfaatan Arang dari Serasah dan Kulit Kayu Pinus. Jurnal Penelitian Hasil Hutan. 22: 17-22

Nurlaeny, N., Marschner, H., dan George, E. (1996). Effects of Liming and Mycorrhizal Colonization on Soil Phosphate Depletion and Phosphate Uptake by Maize (Zea Mays L.) and Soybean (Glycine Max L.) Grown in Two Tropical Acid Soils. Plant and Soil. 181:275-85.

O'Connor, P. J., Smith, S. E., dan Smith, F.A. (2001). Arbuscular Mycorrhizal Associations in the Southern Simpson Desert. Australian Journal of Botany. 49: 493-499

Sharma, A. R., dan Mittra, B.N. (1991). Effect of Different Rates of Application of Organic and Nitrogen Fertilizers in a Rice-Based Cropping System. The Journal of Agricultural Science. 117: 313-318.

Singh, S. (2004). Effect of Soil PH on Mycorrhiza in Agricultural Crops. Mycorrhizal News. $16: 2-8$ 
Sofyan, E. T., dan Sara, D.S. (2018). The Effect of Organic and Inorganic Fertilizer Applications on N, P and K Uptake and Yield of Sweet Corn (Zea Mays Saccharata Sturt). Journal Tropical Soils. 23: 111-116.

Talanca, A. Haris. 2015. Manfaat Mikoriza Vesikular-Arbuskular (MVA) terhadap Pertumbuhan dan Pengendalian Penyakit Tanaman. Paper dipresentasikan di Seminar Ilmiah dan Pertemuan Tahunan PEI dan PFI XVI Sulawesi Selatan.

Winarso. (2005). Kesuburan Tanah: Dasar Kesehetan dan Kualitas Tanah. Gaya Media, Yogyakarta. 270p 